\title{
An Analysis of the Spelling and Meaning of British and American English Words
}

\author{
Suhartatik \\ Program Studi Pendidikan Bahasa Inggris FPISH IKIP Budi Utomo \\ Jalan Citandui 46 Malang
}

\begin{abstract}
Abstrak: Bahasa yang digunakan di dunia ini sangat beragam dan mempunyai karakteristik yang berbeda. Hal ini dapat dipengaruhi oleh letak geografis, latar belakang budaya maupun perbedaan bangsa. Bahasa Inggris sebagai bahasa Internasional mempunyai banyak ragam dialek, misalnya dialek British dan America yang sangat menarik untuk dianalisa. Terdapat banyak perbedaan antara Bahasa Inggris British dan America dimana keduanya saling mempengaruhi. Penelitian ini adalah penelitian deskriptif yang mendeskripsikan tentang analisa dan temuan perbedaan ejaan dan arti kata Bahasa Inggris British dan America. Akhir dari penelitian ini menghasilkan deskripsi yang beragam tentang perbedaan ejaan dan arti kata antara Bahasa Inggris British dan America.
\end{abstract}

Kata kunci: dialek bahasa Inggris British, bahasa Inggris America

Language is many things - a system of communication, a medium for thought, a vehicle forliteraryexpression, a socialinstitution, amatter for political controversy or a factor in nation building.(O'Grady, 2000). Many languages in the world and their characteristics are various. It is caused by the variety of geographical and cultural background, typical and difference of nation, etc. Language in the world are not static but dynamic. They always develop from one generation to the next. The dynamism of language is caused by the dynamism of the users of the language. It means that language always develops every time. It can be seen from the behavior of the users of language especially in their spelling and meaning of sentence matters. [https://wiki.ubuntu.com - accessed on February 2010].

English as an International language, has an important function, and it is one of the great language which is recognized by all nations in the world. It has many dialects. Not only does it change from city to city throughout England, but also from country to country. Among English dialect above, British and American are the most interesting ones to compare. Especially in daily activities, common people know that English is only one, but in the reality, the people, teachers or students who are studying English do not realize that British and American English have some differences in vocabulary, spelling, pronunciation expression and meaning. The difference between British and American English dialects, both in speaking and writing, spelling and meaning are very much a matter of personal choice. Dialect becomes the standard for written and spoken language all over the country, specially British and American English.

Society and culture are one unit that can not be separated from the real-life. The culture is created by human beings in society, because culture is the activity manifestation of the society habit.

One of the society culture is language. Language came to the human beings since people were born. That language, by people or society is recognized as culture that must be kept, developed it survival as fundamental aspects that must be expressed to the next generation, and it is used as the first instrument in communication each other to express ideas and emotion. (Hudson, 1999)

All languages in the world have spelling and meaning. Spelling and meaning are the important aspects which must be investigated by teacher or students who study language. Spelling and meaning are series of means of language to express words, phrases or sentences. On the other hand, the writer thinks no language have not spelling and meaning. 
Spellingandmeaninginlanguage separately has different function. Spelling is classified in phonology branch and it is called orthography, and meaning is studied in semantic field. Both of them have closed relationship that cooperates to be a good language. [//F:American and British English Spelling differences.htm]

Today in out life, there are two English languages famous exist in people life: British English and American English. Both languages have many contribution words from the other language. It means that not only the words they use are original, but also from another country.

As English speaking are influenced by the foreign language such as: American Indian influence, French influence, Spanish influence, Dutch influence, African influence. According to Hudson (1999) there are differences between British and American English, he stated as follows:

It is well-known that the British use the vowel sound represented as /a/ in "father" in such words as "fast", "class" and "dance", where most American use the sound represented as /a/ in "cat".

Other feature of British English are the long /e/ (of "eve") at the beginning of such words as "evolution" and the pronunciation of words ending with "ile" to ryme with "file", "fragile", "mobile", etc. American pronouns some "ile" words that way (juvenile, textile), but so many as the British do.

A difference that is easy to hear but not so easy to describe is the difference in the intonation patterns of British and American English. Intonation refers to the raise and fall of speech without special attention to the words themselves. British English is characterized by more rises and falls stronger accents than are found in American English.

According to Jones (2009) for grammatical points, there are only point in morphology and syntax, with many of these affecting individual items, and very few being general points of syntactic construction (American English examples precede British English in the following; for grammatical terminology).

First, in the verb phrase, AmE prefers "have" to "have got" for possession (Do you have the time? VS Have you got the time?), answer also tend to vary (I do not VS I have not). AmE also sometimes uses a simple past tense where BrE has a present perfect (I just ate VS I have just eaten).
Second, in the noun phrase there are some differences of word order ( $a$ half hour VS half an hour) and the use of article (in the future VS in future; in the hospital VS in hospital). American prefer collective nouns in the singular (the government is, WHERE AS BrE allows plural (the government are).

Third, clausal patterns sometimes differs, as in AmE (come take a look VS come and take), AmE also makes more use of the subjunctive as (I asked that he go VS I asked him to go).

Fourth, there are several differences in preposition and adverbs, such as AmE (I will go momentarily VS in a moment; real good VS really good), and backward VS backwards.

In general there are some differences between British and American English spelling. In the early $18^{\text {th }}$ century, English spelling was not standardized. Differences became noticeable after the publishing of influential dictionaries of Noah Webster in his American Dictionary of the English Language of 1828. Webster had a strong proponent of spelling reform for reasons nationalistic and philosophical (Webster, 2000).

On the other hand, spelling reform in England influenced by Norman (Anglo-French) spellings of certain words proved decisive. Spelling adjustments in the UK had little effect on present-day US spelling, and vice-versa. The spelling systems of Commonwealth countries, for the most part closely resemble the British system. In Canada, however, while most spelling is British, many American spelling are also used. [File //F: \American and British English Differences.htm]. Whether British or American English, to spell words are not easy for teacher or student. In British and American English there are several words confusion to spell. They are the words only different of one two alphabet with different meaning.

Studying on the meaning means study the word that has two meanings. In the semantic field, studying the word that has two meanings is called "lexical relation" (O'Grady, 2000). In English language, British or American English, the teachers or the students do not investigate the one word with different meaning, but also two words of different form of one or the same meaning. The kinds of different form of British and American English do not much pay attention by the speakers. The difference of word but has the same meaning is the minor expression than the words with has two 
meaning British and American [//F:| |esl.fis.edu/ grammar/easy/aedebe.htm].

Based on the background above, this study will analyses of British and American English spelling and words meaning. The problem of this study are: (1) What British and American English words have different spelling words in Webster and Oxford dictionary?; (2) What British and American English words have different meaning in Webster and Oxford dictionary? The purpose of this study are: (1) to find out British and American English words in Webster and Oxford dictionary that have different spelling; (2) to find out British and American English words in Webster and Oxford dictionary that have different meaning. The scope and limitation of the study deal with the analysis of British and American words English that have differences in spelling and meaning.

\section{METHOD}

This study is designed to be descriptive research with the aim of describes the analysis and discussion of the different of spelling and meaning of British and American English words. This study will covers: (a) to examine and identifies the spelling of British and
American English words and; (b) to examine and identifies the meaning of British and American English words. The data analysed are the British and American English words that have different spelling and meaning. Other sources are from Hornby, 2002. Oxford Advanced Learner's Dictionary of Current English $.9^{\text {th }}$ Edition. London. Oxford University Press and Webster. 2000. Webster's Dictionary of the American Language. The data are obtained by: (1) collecting English words in Webster and Oxford dictionary; (2) selecting English words that have different spelling; (3) selecting English words that have different meaning.

For data analysis. First, the writer analyses and classifies British and American English words having different spelling. Second, the writer analyses and classifies British and American English words having different meaning.

\section{FINDING AND DISCUSSION}

\section{Different Spelling}

British and American English words that have different spelling but the same meaning can be classified as follows: (/F: $\backslash$ differences spell.htm down loaded on March 15, 2009).

List of the Differences of British and American English words spelling -re and -er.

\begin{tabular}{|c|c|c|}
\hline BRITISH ENGLISH & AMERICAN ENG- & MEANING \\
\hline SPELLING & LISH SPELLING & \\
\hline accourtrements & accourterments & equipment \\
\hline centre & center & place from which administration is organized \\
\hline epicentre & epicenter & $\begin{array}{l}\text { place from which an earth quake reaches the earth's } \\
\text { surface }\end{array}$ \\
\hline fibre & fiber & material or substance formed from a mass of fibres \\
\hline litre & liter & unit of capacity in the metric system \\
\hline metre & meter & unit of length in the metric system \\
\hline theatre & theater & $\begin{array}{l}\text { building or outdoor area for the performance of } \\
\text { plays and similar entertainments. }\end{array}$ \\
\hline
\end{tabular}

List of the differences of British and American English words spelling - our and -or

BRITISH ENGLISH
SPELLING
behaviour
colour
dishonour
flavour
neighbour

$\begin{array}{ll}\text { AMERICAN ENG- } & \text { MEANING } \\ \text { LISH SPELLING } & \\ \text { behavior } & \text { manners } \\ \text { color } & \text { put colour or something by painting. } \\ \text { dishonor } & \text { loss of honour or respect. } \\ \text { flavor } & \text { taste and smell especially for food } \\ \text { neighbor } & \text { person living next to near or another }\end{array}$


70 | Suhartatik, An Analysis of the Spelling and Meaning ...

List of the differences of British \&American English words spelling - ouge and -og

\begin{tabular}{|c|c|c|}
\hline $\begin{array}{l}\text { BRITISH ENGLISH } \\
\text { SPEIISG }\end{array}$ & AMERICAN ENG- & MEANING \\
\hline $\begin{array}{l}\text { SPELLING } \\
\text { analogue }\end{array}$ & $\begin{array}{l}\text { LISH SPELLING } \\
\text { analog }\end{array}$ & thing that is similar to another thing. \\
\hline demagogue & demagog & $\begin{array}{l}\text { political reader who tries to win people's support } \\
\text { by using emotional and un-resonable argument. }\end{array}$ \\
\hline dialogue & dialog & $\begin{array}{l}\text { discussion between people with different opin- } \\
\text { ions. }\end{array}$ \\
\hline epilogue & epilog & $\begin{array}{l}\text { sort speech or poem spoken by one of the charac- } \\
\text { ters at the end of the play. }\end{array}$ \\
\hline monologue & monolog & long speech in a play, film spoken by one actor. \\
\hline
\end{tabular}

List of the differences of British and American English words spelling - ise and - ize

$\begin{array}{lll}\begin{array}{l}\text { BRITISH ENGLISH } \\ \text { SPELLING } \\ \text { advertisement } \\ \text { analyse }\end{array} & \begin{array}{l}\text { AMERICAN ENGLISH } \\ \text { SPELLING } \\ \text { advertizement } \\ \text { analyze }\end{array} & \begin{array}{l}\text { MEANING } \\ \text { action of advertising } \\ \text { separate something people with different } \\ \text { opinions } \\ \text { provide a computer to do the work of or for } \\ \text { something } \\ \text { cause something to form into crystal } \\ \text { crystalise }\end{array} \\ \begin{array}{l}\text { computerize } \\ \text { decentralise }\end{array} & \begin{array}{l}\text { cristalize } \\ \text { decentralize }\end{array} & \text { ment }\end{array}$

List of the differences of British and American English words spelling - ence and -ense

\begin{tabular}{|c|c|c|}
\hline BRITISH ENGLISH & AMERICAN ENG- & MEANING \\
\hline SPELLING & LISH SPELLING & \\
\hline defence & defense & defending from attack \\
\hline licence & license & $\begin{array}{l}\text { official document showing permission has } \\
\text { been given to own, use or do something }\end{array}$ \\
\hline offence & offense & breaking off a rule or law illegal act \\
\hline pretence & pretense & deception, make believe \\
\hline
\end{tabular}

List of the differences of British and American English words spelling - $l l$ and $-l$

\begin{tabular}{|c|c|c|}
\hline $\begin{array}{l}\text { BRITISH ENGLISH } \\
\text { SPELLING }\end{array}$ & $\begin{array}{l}\text { AMERICAN ENG- } \\
\text { LISH SPELLING }\end{array}$ & MEANING \\
\hline bejewelled & bejeweled & decorated with jewels \\
\hline chilli & chili & $\begin{array}{l}\text { small pod of a type of paper plant, often dried } \\
\text { or made into poweder and used to give a hot } \\
\text { taste to food }\end{array}$ \\
\hline counsellor & counselor & advisor \\
\hline install & instal & $\begin{array}{l}\text { fix equipment in position for use, especially } \\
\text { connections with the supply of water, electricity. }\end{array}$ \\
\hline travelled & traveled & having traveled to many places \\
\hline jeweller & jeweler & a person who sell and make jewellery \\
\hline snorkelling & snorkeling & action or sport of swimming with a snorkel \\
\hline
\end{tabular}

List of the differences of British \& American English words spelling -ae, -oe and -e

BRITISH ENGLISH

SPELLING

aesthetic

\author{
AMERICAN ENG- \\ LISH SPELLING \\ esthetic
}

MEANING

appreaciating beauty and beautiful thing 


$\begin{array}{ll}\text { anaemia } & \text { anemia } \\ \begin{array}{l}\text { anaesthesia } \\ \text { encyclopaedia }\end{array} & \begin{array}{l}\text { anesthesia } \\ \text { encyclopedia }\end{array} \\ \text { haemoglobin } & \text { hemoglobin }\end{array}$

medical condition of the blood caused by lack of red corpuscles

state of being enable to feel pain, heat or cold book or set of books giving information knowledge, or about one particular subject substance carrying oxygen in the red blood cells of vertebrates

\begin{tabular}{|c|c|c|}
\hline $\begin{array}{l}\text { BRITISH ENGLISH- } \\
\text { SPELLING }\end{array}$ & $\begin{array}{l}\text { AMERICAN ENG- } \\
\text { LISH SPELLING }\end{array}$ & MEANING \\
\hline aeroplane & airplane & aircraft \\
\hline centigramme & centigram & one $100^{\text {th }}$ part of a gram \\
\hline cigarette & cigaret & material for smoking \\
\hline cheque & check & $\begin{array}{l}\text { special printed form on which onwrite an order } \\
\text { to a bank to pay some money from one's ac- } \\
\text { count to another person }\end{array}$ \\
\hline fulfil & fulfill & bring to completion \\
\hline grey & gray & grey of the colour between black and white \\
\hline programme & program & plan of what is intended to be done \\
\hline plough & plow & break up the surface of the land with a plough \\
\hline
\end{tabular}

Based on the result of the analysis above, the writer indicates that the difference of spelling of British and American English words can be classified as follows :

1. Spelling - re and - er. The words that have spelling -re are British English, meanwhile spelling -er is American English spelling. The difference of spelling -re and -er in metre/meter; kilometre/kilometer are specialized for the length size, it is not for noun, such as thermometer.

2. Spelling - our and -or. Spelling -our only occurs in British English, while spelling -or in American English spelling.

3. Spelling - ogue and - og. Spelling - ogue is British English spelling, while spelling -og is American English spelling.

4. Spelling - ise and -ize . Spelling - ise is British English spelling, while spelling - ize is American English spelling.
5. Spelling - ence and - ense. Spelling - ence is British English spelling, while spelling - ense is American English spelling.

6. Spelling - ll and - $l$. Double spelling is British English spelling, while single spelling is American English spelling.

7. Spelling - ae/oe and - e. Spelling - ae/oe is British English spelling, while spelling $-e$ is American English spelling.

8. Individual spelling is irregular spelling, It has no rules or indicator the characteristics of British and American English spelling.

\section{Diffferent Meaning}

The words whose meaning will be analyzed in this study are British and American English words having different meaning. (/F: $\mid$ data net $\mid$ meaning.htm - down loaded on March 11, 2009). 
72 | Suhartatik, An Analysis of the Spelling and Meaning ...

\section{List of British and American English words that are different in meaning}

\begin{tabular}{|c|c|c|}
\hline $\begin{array}{l}\text { WORDS } \\
\text { agency }\end{array}$ & $\begin{array}{l}\text { BRITISH ENGLISH MEANING } \\
\text { business or place of business provid- } \\
\text { ing a service }\end{array}$ & $\begin{array}{l}\text { AMERICAN ENGLISH MEANING } \\
\text { government office providing a specific } \\
\text { service }\end{array}$ \\
\hline attorney & $\begin{array}{l}\text { person appointed to act for another } \\
\text { in business or legal matter }\end{array}$ & lawyer \\
\hline bureau & writing desk with drawers & government department \\
\hline panther & leopard & puma \\
\hline purse & small bag for money & handbag \\
\hline
\end{tabular}

Based on the data, the writer indicates that one word can be have two meaning both on British and American English.

\begin{tabular}{|c|c|c|}
\hline $\begin{array}{l}\text { BRITISH ENGLISH } \\
\text { FORMS }\end{array}$ & $\begin{array}{l}\text { AMERICAN ENGLISH } \\
\text { FORMS }\end{array}$ & MEANING \\
\hline about & around & approximately \\
\hline apartment & flat & $\begin{array}{l}\text { set of rooms, usually furnished and rented } \\
\text { especially for holiday }\end{array}$ \\
\hline angry & mad & filled with anger \\
\hline autumn & fall & $\begin{array}{l}\text { the third season of the year coming between } \\
\text { summer and winter }\end{array}$ \\
\hline bill & check & $\begin{array}{l}\text { written statement of money owed for goods/ } \\
\text { service supply }\end{array}$ \\
\hline curriculum vitae & resume & $\begin{array}{l}\text { brief account of somebody's previous car- } \\
\text { rier }\end{array}$ \\
\hline
\end{tabular}

Based on the analysis above, the writer finds that some British and American English words have different forms. Between British and American English forms, there are some words have different meaning, for example "angry and mad " angry (BrE) and mad (AmE). "Mad" in British is insane. It does not mean "angry" in BrE.

"Timber and Lumber" Timber or Lumber in BrE and AmE English is wood. Meanwhile "Lumber" in BrE is "junk or rubbish". Based on the result of the study, it is proved that there are some different in spelling and meaning. Differences in spelling are -re and -er;

1-our and-or;-ogue and-og; ise and-ize;-ence and - ense; - Il and - l; -ae, oe and -e and individual spelling. Besides the differences of spelling, there are also differences of meaning and multiple meaning. In general, the differences of spelling and meaning between British and American English, are historically influenced by the differences of words' adding since Elisabethan times.

First, historically, some of words of British English are taken from Latin and Greek sources, while American English mostly taken from
French, Spanish, Dutch and African influences. Second, based on geographical, the differences of British and American English are based on the location on different continent. England is located on European continent, and arounded by the Atlantic Ocean. Whereas America is located on American continent and arounded by the Pacific Ocean. Therefore the reason above cause British and American English come to different, such as culture, expression, pronunciation, spelling and meaning.

\section{CONCLUSION AND SUGGESTION}

Based on the analysis and discussion, the writer concludes that :

1. There are some British and American English words that have different spelling, such as "lustre andluster"; "harbour andharbor; "analyse and analyze"; "defence and defense","travelled and traveled"; "programme and program"; "haemoglobin and hemoglobin" etc.

2. There are some British and American English words that have different meaning, such as agency, attorney, banner, bureau, faucet, kid, panther, trash, vacation, etc. 
British English tends to use suffixes: - re, - our, - ogue, - ise; - ence, while American tend to use suffixes : - er, -or; - ize; ense, etc.

There are suggestions for the lecturer. First, they have to give clear explanation concern with British and American English covering different spelling, meaning, or forms. It is also essential for improving speaking ability or to enlarge students' vocabulary.

For the student, they can develop and explore their knowledge concerning with British and American English, they can download from internet or go to the library as their references. Third, the student should practice how to pronounce British and American English well, by watching television, listening songs or joining English club, etc.

\section{REFERENCES}

Absolute Astronomy.com. 2009. American and british English Spelling. Accessed on March 11, 2009. (http://F:\American and British English Spelling.htm.)

Bloomfield. L. 1999. Language. New York. Holt, Rinehard and Winston.
Hornby, A.S. 2002. Oxford Advanced Learner's Dictionary of Current English . $9^{\text {th }}$ Edition. London. Oxford University Press.

Hudson, R.A. 1999. Sociolinguistics. New York. Cambridge Univ.Press.

(http://F: \datanet/meaning.htm. download on March 11, 2009

(http://F: \differences spell.htm. download on March, 2009.

Jones, Susan. 2009. American vs British Spelling Differences. [https://wiki.ubuntu.com. accessed on February $\left.1^{\text {st }} 2010\right]$

King, Larry. 1999. Seni Bahasa Kepada Siapa Saja. Kapan Saja.Dimana Saja. Jakarta. PT. Gramedia.

O'Grady, Dobrovolsky, Aronoff. 2000. Contemporary Linguistics An Introduction. U.S.A. St.Martin's Press.

Sari, Nirmala. 2001. Intoduction to Linguistics. Jakarta. Direktorat Pendidikan Tinggi.

Suharsimi, A. 2006. Penelitian. Jakarta. PT.Gramedia.

Webster, M. 2000. Webster's Dictionary of the American Language.. USA. Book Craft Guild, Inc. 
74 | Suhartatik, An Analysis of the Spelling and Meaning ... 